\title{
Wincenty Skrzetuski o wzajemnych relacjach stanów sejmujących w Rzeczypospolitej szlacheckiej (wybrane zagadnienia)
}

Inspiracją do przyjrzenia się problematyce relacji pomiędzy stanami sejmującymi w Rzeczypospolitej szlacheckiej były liczne spostrzeżenia i uwagi Profesora Ryszarda Łaszewskiego, jakie Jubilat zawarł w swoim fundamentalnym do dziś dziele o Sejmie Rzeczypospolitej szlacheckiej doby stanisławowskiej ${ }^{1}$. Zagadnienie relacji pomiędzy stanami sejmującymi, a przede wszystkim pomiędzy władzą ustawodawczą, wykonawczą i sądowniczą w dawnej Rzeczypospolitej było dyskutowane w 2. połowie XVIII wieku, choć już wcześniej szlacheckie elity nie raz rozważały i spierały się w takich kwestiach jak np. zakres władzy i stosunki pomiędzy królem, senatem i izbą poselską. Przyjęta za sprawą konstytucji Nihili novi formuła sprawowania najwyższej władzy przez mające się równoważyć trzy stany sejmujące nie przesądzała jednoznacznie o sposobie jej wykonywania oraz o wzajemnych relacjach pomiędzy poszczególnymi „władzami” szlacheckiego państwa, tym bardziej że kompetencje te niejednokrotnie na siebie „nachodziły”, a czego nie uznawano za stan niezgodny z prawem. Należy podkreślić, że pierwsze przemyślane i oparte na dotychczasowych, nieraz bolesnych, doświadcze-

\footnotetext{
1 R. Łaszewski, Sejm polski w latach 1764-1793. Studium historyczno-prawne, Warszawa-Poznań 1973.
} 
niach propozycje zmian pojawiły się jeszcze w XVII stuleciu. Godne odnotowania są propozycje mające na celu ograniczenie czy ściślejsze określenie zakresu władzy senatu, izby poselskiej, poszczególnych ministrów, a także samego króla, w tym nawet zastąpienia tego ostatniego innym organem lub wprowadzeniem dziedzicznej monarchii. Rzeczywiste zmiany i poważniejsze reformy zaczęto wprowadzać dopiero od 1764 roku, co było kontynuowane ze zmiennym szczęściem aż do Sejmu Wielkiego, kiedy to obszernie i długo dyskutowano nad problemem reformy władz publicznych, w tym uregulowania ich wzajemnych relacji oraz bardziej przejrzystego rozgraniczenia ich kompetencji, sposobu wzajemnej kontroli czy odpowiedzialności. Zanim jednak doszło do rozważania tych kwestii na Sejmie Czteroletnim, już wcześniej podnoszone były głosy zachęcające do gruntownej przebudowy struktur władzy państwowej, $\mathrm{w}$ tym m.in. do zmiany sposobu wyboru panującego oraz nowego uregulowania jego relacji $z$ pozostałymi stanami sejmującymi. W gronie kilku najważniejszych projektodawców i propagatorów reform nawiązujących m.in. myśli Stanisława Konarskiego był także inny pijar Wincenty Skrzetuski. Ciekawe zatem wydaje się skonfrontowanie ustaleń Profesora Ryszarda Łaszewskiego z niektórymi poglądami Skrzetuskiego w zakresie relacji pomiędzy stanami sejmującymi, jakie pijar zawarł w swoim podręczniku o Prawie politycznym narodu polskiego. Należy zaakcentować, że Skrzetuski był w zasadzie pierwszym pisarzem politycznym, który tak obszernie opisał przeobrażenia ustrojowe, jakie nastąpiły w dobie stanisławowskiej do czasów Sejmu Czteroletniego. Działalność Skrzetuskiego na tym polu była jednym $z$ ważniejszych elementów wielkiego podręcznikowego zamierzenia pijarskiego, przedstawienia ustroju państwa szlacheckiego i obowiązującego w nim prawa, w tym także zmian, jakie zaszły w sposobie organizacji i rządzenia państwem szlacheckim po pierwszym rozbiorze.

Wincenty Skrzetuski żył w latach 1745-1791 i był uznanym pedagogiem, historykiem, prawnikiem i pisarzem politycznym doby stanisławowskiej. W jego dorobku odnajdziemy kilka ciekawych prac z zakresu historii, myśli politycznej i prawa, w tym przede wszystkim Mowy o główniejszych materiach politycznych, które dały mu pozycję uznanego pisarza politycznego, ugruntowaną po opu- 
blikowaniu w latach 1782-1784 Prawa politycznego narodu polskiego. W 1783 roku Skrzetuski przygotował skrócony przekład dzieła Mably'ego O prawodawstwie czyli o pierwszych zasadach praw. Ważne miejsce w pisarstwie Skrzetuskiego miała historia. Już w 1772 roku wydał Dzieje królestwa szwedzkiego od panowania Waldemara, to jest od roku 1250 aż do niniejszego roku według lat porzadku opisane. W 1786 roku Skrzetuski na zamówienie Towarzystwa do Ksiąg Elementarnych napisał Historię powszechna dla szkół narodowych na klasę IV, dzieje greckie zawierającą. Należy także wskazać, że najprawdopodobniej w trakcie Sejmu Wielkiego Skrzetuski wspólnie $z$ kilkoma innymi pijarami (Józefem Konstantym Bogusławskim i Franciszkiem Ksawerym Dmochowskim) pisał dla posłów stronnictwa patriotycznego głosy i mowy sejmowe 2 .

Na wstępie swoich rozważań o sejmach Rzeczypospolitej szlacheckiej Skrzetuski podkreślał, że wszelka władza w Polsce należy do narodu i jest sprawowana przez trzy stany: królewski, senatorski i rycerski ${ }^{3}$. Pijar za początek nowożytnego sejmu uznawał zjazdy walne, które odbywały się w okresie rządów Jagiellonów, a w których brali udział nie tylko przedstawiciele rady królewskiej, ale cała

${ }^{2}$ Do najważniejszych prac Wincentego Skrzetuskiego należy zaliczyć: Dzieje królestwa szwedzkiego od panowania Waldemara, to jest od roku 1250 aż do niniejszego roku według lat porzadku opisane, Warszawa 1772; Mowy o główniejszych materiach politycznych, Warszawa 1773; Prawo polityczne Narodu Polskiego, Warszawa 1782-1784, wydanie drugie poprawione ukazało się w 1787 roku i ono jest podstawą moich rozważań; przekład dzieła G. De Mably, O prawodawstwie czyli o pierwszych zasadach praw, Warszawa 1783; Historia powszechna dla szkół narodowych na klasę IV, dzieje greckie zawierajaca, Kraków 1786. Szerzej postać Skrzetuskiego prezentują: F. Bentkowski, Żywot i prace uczone ks. Wincentego Skrzetuskiego S.P., [w:] Posiedzenie publiczne Królewskiego Warszawskiego Uniwersytetu na uczczenie pamiątki zmarłych mężów odbyte dnia 14 lipca 1827 roku, Warszawa 1827, s. 7-17; E. Aleksandrowska, Skrzetuski Bartłomiej imię zakonne Wincenty, [w:] Polski słownik biograficzny, t. XXXVIII, s. 435-437.

3 Pijar ujmuje to następująco: „Całowładność Narodowa w Polszcze w trzech Rzeczypospolitej Stanach Królewskim, Senatorskim i Rycerskim zamknięta będąc, na Seymach okazuie się", W. Skrzetuski, Prawo polityczne, t. I, s. 266. 
obecna na zjazdach szlachta, która $z$ czasem wyłaniała ze swojego grona posłów ${ }^{4}$.

Omawiając wzajemne relacje pomiędzy stanami sejmującymi, polski pijar szczegółowo opisywał w kolejnych rozdziałach swojego podręcznika o prawie politycznym podmioty biorące udział w obradach sejmu, przypominając przy tym, że parlament szlachecki składał się z króla, senatorów z ministrami i posłów ziemskich. Ukazywał, że warunkiem legalności obrad parlamentu szlacheckiego był osobisty w nich udział monarchy lub jego zgoda na ich prowadzenie $^{5}$.

Odnosząc się do wzajemnych relacji stanów sejmujących przy okazji prezentowania problemu inicjatywy ustawodawczej, którą przypisywał monarsze przy okazji realizacji prawa do zwoływania sejmików przedsejmowych, Skrzetuski skwapliwie akcentował zwyczaj konsultowania przez króla tematyki obrad sejmu początkowo

4 Pijar akcentował przy tym, że „żaden Zjazd walny nie mógł być prawnie złożony bez przytomności posłów ziemskich, wtedy dopiero Seymy całowładności nabyły”, ibidem, s. 267-268.

${ }^{5}$ Pijar powołuje się na przypadek z 1652 roku. Szerzej zob.: W. Czapliński, Dwa sejmy $w$ roku 1652. Studium z dziejów rozkładu Rzeczypospolitej $w$ XVII wieku, Wrocław 1955, s. 153. Skrzetuski przy tej okazji zapewne za Lengnichem przypomina też sejm z 1668 roku, kiedy do król Jan Kazimierz za zgodą senatorów $z$ uwagi na przeciągającą się w nocy sesję udał się na spoczynek wbrew woli posłów, a co ci ostatni uznali za zerwanie obrad parlamentu, G. Lengnich, Prawo pospolite Królestwa Polskiego, Kraków 1836, s. 164, 511. Pijar przywoływał też sejm z 1733 roku, który rozszedł się zaraz po wiadomości o śmierci króla Augusta II Wettina. W. Skrzetuski, Prawo polityczne, t. I, s. 104-105. Por. K. Grzybowski: Teoria reprezentacji $w$ Polsce epoki Odrodzenia, Warszawa 1959, s. 91 i n. O nieudanej próbie Czartoryskich rozpoczęcia sejmu pod nieobecność króla Augusta III w 1756 roku pisze np. W. Konopczyński, Polska w dobie wojny siedmioletniej, t. I, Warszawa 1911, s. 170. Pijar podawał, że zdarzało się czasami, iż obrady toczyły się pod nieobecność władcy na prośbę samych parlamentarzystów, którzy „postrzegając jakie ubliżenie prawom, chcieli mieć większą w naradzaniu się wolność i żeby w przypadku potrzeby ostrzeżenia w czym króla, nikt osobiście nienawiści nie popadł", W. Skrzetuski, Prawo polityczne, t. I, s. 105-106. Zob. R. Łaszewski, Sejm, s. 27-33. Por. też H. Olszewski, Sejm Rzeczypospolitej epoki oligarchii 1652-1763, Poznań 1966, s. 136. 
z radą senatu, a po 1775 roku z Radą Nieustającą. Skrzetuski akcentował także, że poza uniwersałami $z$ kancelarii królewskiej wysyłane są do senatorów oraz urzędników listy informujące o zwoływaniu sejmu i sejmików oraz że od 1717 roku listy takie należało wysyłać $z$ co najmniej trzymiesięcznym wyprzedzeniem ${ }^{6}$.

Warto w tym miejscu zauważyć, że Skrzetuski w swoim podręczniku zwrócił także uwagę na próby podważania nadrzędnego stanowiska sejmu przez sejmiki, które $z$ różnych powodów uzurpowały sobie kompetencję ustawodawczą parlamentu. W związku z tym pijar starał się dość jasno wyłożyć, nie zawsze ściśle rozgraniczone, kompetencje sejmu i sejmików. Dodatkowo warto podkreślić, że Skrzetuski zauważał także rolę i znaczenie króla i dworu dla całego procesu ustawodawczego, w tym także kwestii zmiany programu obrad w toku samego sejmu. Ważnym zagadnienie jakie poruszał Skrzetuski była sprawa charakteru i treści instrukcji poselskich. Pijar wyjaśniał cele i powody, dla których powstała w ogóle potrzeba spisywania instrukcji, o czym, m.in. pisał: „Stan rycerski wszystek do władzy Prawodawczey należąc, a nie mogąc iey sprawować, iak Senat, w zupełnym Zgromadzeniu swoim na Seymie, lecz tylko przez wybranych od siebie Posłów działać musząc, tych woli swoiey składem czyni, tym przypisuie Instrukcye, których się nieodstępnie

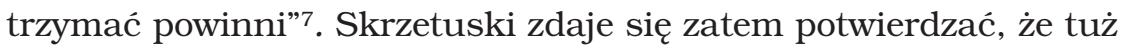
przed Sejmem Wielkim mandat poselski miał nadal charakter imperatywny. Spostrzeżenie pijara jest dla nas tym bardziej cenne, że zagadnienie instrukcji i ich skutków prawnych nie znalazło jednoznacznego uregulowania w prawie stanowionym Rzeczypospolitej szlacheckiej ${ }^{8}$. Skrzetuski podkreślał, iż w treści instrukcji miano uwzględniać wszystkie sprawy dotyczące interesów państwa zakreślone w uniwersałach i wystąpieniach posłów królewskich oraz

6 W. Skrzetuski, Prawo polityczne, t. I, s. 272, 284; R. Łaszewski, Sejm, s. 33-34.

7 W. Skrzetuski, Prawo polityczne, t. I, s. 257-258.

8 A. Lityński, Sejmiki ziemskie 1764-1793. Dzieje reformy, Katowice 1988, s. 140-147. Por. H. Olszewski, Sejm, s. 110; K. Grzybowski, Teoria reprezentacji, s. 53; S. Płaza, Sejmiki i zjazdy szlacheckie województw poznańskiego i kaliskiego. Ustrój i funkcjonowanie (1572-1632), Warszawa-Kraków 1984, s. 123. 
wskazywał, że w instrukcjach dodawane są ponadto inne sprawy zarówno publiczne, jak i prywatne, które zdaniem szlachty zgromadzonej na sejmiku winny przybrać postać uchwał sejmowych. Pijar, odwołując się do konstytucji z 1768 roku, podkreślał, że w treści instrukcji mogą się znaleźć tylko te kwestie, co do których umieszczenia i przedstawienia na sejmie zgodziła się cała szlachta na sejmiku lub co najmniej jej większość. Przed głosowaniem projekt instrukcji miał być najpierw omówiony, następnie spisany, głośno wszystkim odczytany, a po przyjęciu podpisany przez marszałka i asesorów sejmiku. Warto zauważyć, że autor Prawa politycznego wskazywał czytelnikom trzy tradycyjne płaszczyzny merytoryczne instrukcji, czyli ustosunkowanie się do propozycji królewskich, projekty dotyczące spraw ogólnopaństwowych nieuwzględnionych przez monarchę oraz petita, $\mathrm{tj}$. projekty lokalne, a nawet osobiste wnoszone przez zgromadzoną na sejmiku szlachtę ${ }^{9}$.

Warto w tym miejscu zauważyć, że przy okazji omawiania problematyki instrukcji sejmikowych oraz sejmików relacyjnych Skrzetuski poruszał także problem konstytucji sejmowych uchwalonych wbrew woli jakiegoś sejmiku. Pijar zdecydowanie stwierdzał przy tej okazji, iż „wszakże chociażby co nie do upodobania Woiewodztwa którego uchwalono na Seymie, nie można tego nie przyiąć, gdyżby to było słabić powagę Seymów, to iest naywyższą Rzeczypospolitey udzielność” ${ }^{10}$.

Prezentując rolę osoby króla w czasie obrad sejmowych, Skrzetuski, odnosząc się do relacji pomiędzy stanami sejmującymi, przypominał, że sesje w senacie „zagaiane i solwowane bywaią

9 W. Skrzetuski, Prawo polityczne, t. I, s. 258. Obszernie na temat instrukcji zob. R. Łaszewski, Instrukcje poselskie $w$ drugiej połowie XVIII wieku, Acta Universitatis Nicolai Copernici. Nauki Humanistyczno-Społeczne, z. 56. Prawo, z. 12, red. W. Szyszkowski, Torun 1973, s. 73 i n.

${ }^{10}$ W. Skrzetuski, Prawo polityczne, t. I, s. 260. Por. Zbiór mów różnych $w$ czasie dwóch seymów ostatnich r. 1775 i 1776 mianych, t. II, Poznań 1777, s. 301; Lauda sejmików Ziemi Dobrzyńskiej, wyd. F. Kulczycki, Kraków 1887, s. 320; Akta grodzkie i ziemskie z archiwum tzw. bernardyńskiego we Lwowie. Lauda sejmikowe wiszeńskie, lwowskie, przemyskie i sanockie 1731-1772, wyd. A. Prochaska, t. XXIII, Lwów 1928, s. 451, 479 . 
powagą i imieniem Króla. Mówiący senatorowie i posłowie, głosy swoie do króla naprzód, a potym do stanów obracają" ${ }^{11}$. Dalsze ślady dotyczące inicjatywy ustawodawczej króla odnajdujemy w rozważaniach o sejmie, gdzie pijar podawał, że po zakończeniu czytania paktów konwentów i wolnych głosów z tym związanych kanclerz przedstawiał stanom propozycje materii sejmowej pochodzące od tron $^{12}$. W sumie $z$ wywodów Skrzetuskiego niewiele można wywnioskować w zakresie inicjatywy ustawodawczej króla oraz jego wpływu na faktyczny przedmiot obrad sejmu, choć jak wiadomo pijar pisał swoje dzieło już po wprowadzeniu zakazu przysięgania na instrukcje sejmikowe, które przez długi czas rozmywały propozycję królewskich legacji na sejmikach przedsejmowych i powodowały, że propozycje od tronu nieraz ginęły w masie partykularnych żądań szlachty.

$Z$ kolei badania nad problemem wpływu króla na uchwały sejmu wskazują, że o ile w XVI wieku władca miał niekwestionowany monopol na kształt konstytucji sejmowych, to już w XVII stuleciu stan ten uległ zmianie. Coraz mniejszy wpływ króla na to, którymi projektami zajmie się sejm merytorycznie, nakazują przyjęcie poglądu o tym, że uprawnienie to król i senat dzieliły z izbą poselską, a pośrednio $z$ całą szlachtą ${ }^{13}$. Sam Skrzetuski niewiele pisał o prawie i sile monarszego głosu, podając jedynie, że na „wszystkich obradach król ostatni głosuje, a zdanie jego wyrokiem seymowym jest i prawem, skoro się w czym nie sprzeciwia albo dawniejszym ustawom, albo prerogatywom szlachty lub duchowieństwa. Wtedy bowiem nie tylko senator, ale i poseł ma wolność oparcia się. Y dla tego w takowych okolicznościach zazwyczaj król, zdanie zawiesiwszy, czeka aż się posłowie z senatorami, a przynajmniej większa ich

11 W. Skrzetuski, Prawo polityczne, t. I, s. 272; R. Łaszewski, Sejm, s. $66-68$.

12 W. Skrzetuski, Prawo polityczne, t. I, s. 284; R. Łaszewski, Sejm, s. $132-134$.

13 R. Łaszewski, Sejm, s. 33-36, 135-136, 138-139. Por. też: H. Olszewski, Sejm, s. 151-152, 162-163; K. Grzybowski, Teoria reprezentacji, s. $175-178$. 
część na jedno zgodzą"14. Pijar wskazywał także, że po zmianach ustrojowych pierwszej dekady rządów Stanisława Augusta „materie status na seymach wolnych jednomyślnością, inne wszelkie większością głosów uchwalone bywają" ${ }^{15}$. Mając na względzie wzajemne relacje stanów sejmujących, warto też zauważyć, iż przy opisie przebiegu obrad sejmu Skrzetuski podawał, że królewski głos decyduje w przypadku równości głosów w sprawach ekonomicznych, a w sprawach materii status ,jednomyślność koniecznie tak jest potrzebna, że każda osoba sejm składająca ma moc zatamowania activitatis sejmu przez swoje nie pozwalam (liberum veto)"16.

Analizując wzajemne relację stanów sejmujących, przyjdzie zatem wskazać, że Skrzetuski nie kwestionował wpływu króla na ustawodawstwo. Na szerszą skalę nastąpiło to zresztą dopiero w dobie Sejmu Wielkiego, choć już w projektach reform ustrojowych prezentowanych w drugiej połowie rządów Augusta III przez Czartoryskich proponowano pozbawienie króla sankcji ustawodawczej, w tym domagano się, aby przyjęte przez obie izby konstytucje były jedynie odczytywane w obecności monarchy. Co więcej, Familia proponowała nawet odebranie królowi prawa stanowczego głosu w senacie ${ }^{17}$. Jak wykazał to R. Łaszewski, powyższe postulaty znalazły częściowo odbicie w niektórych propozycjach na sejmie konwokacyjnym w 1764 roku oraz w uchwałach sejmu koronacyjnego,

14 W. Skrzetuski, Prawo polityczne, t. I, s. 272-273; R. Łaszewski, Sejm, s. $142-147$.

15 W. Skrzetuski, Prawo polityczne, t. I, s. 273; Skrzetuski opierał się zapewne na prawach kardynalnych, które m.in. stanowiły, że „Moc prawodawstwa dla Rzplitej w trzech stanach, to jest królewskim, senatorskim i rycerskim dotąd trwająca niewzruszoną na zawsze zostawać powinna i tej mocy jeden stan bez dwóch drugich, ani dwa bez trzeciego przywłaszczać sobie, ani zażywać nie będą mogły”, Volumina Legum, wyd. J. Ohryzko, Petersburg 1860 (dalej: VL), t. VII, s. 277 i n. Por. R. Łaszewski, Sejm, s. $143-144$.

16 W. Skrzetuski, Prawo polityczne, t. I, s. 288. Por. VL, t. VII, s. 290; R. Łaszewski: Sejm, s. 145-146.

17 S. Konarski, O skutecznym, t. IV, s. 244; W. Konopczyński, Polscy pisarze polityczni XVIII wieku (do Sejmu Czteroletniego), Warszawa 1966, s. 122; J. Michalski, Plan Czartoryskich naprawy Rzeczypospolitej, Kwartalnik Historyczny 1956, t. LXIII, s. 36 i n. 
który stał na stanowisku ważności całego ustawodawstwa okresu bezkrólewia po śmierci Augusta III ${ }^{18}$.

Warto zauważyć, że z opisu Skrzetuskiego nie można jednoznacznie wywnioskować, czy i ewentualnie w jakim zakresie król brał udział w redagowaniu i konkludowaniu uchwał przyjętych w obu izbach, w tym także po ich połączeniu. Tym samym pijar nie poszerzył naszej wiedzy w zakresie tego, jaki był ewentualny wpływ i możliwości korekty przez króla przedstawionych w połączonych izbach projektów uchwał sejmu i jakie w tym zakresie były relacje między stanami sejmującymi ${ }^{19}$. Należy także dodać, że wśród uprawnień króla Skrzetuski bez jakichkolwiek wyjaśnień wymieniał wyłączne prawo ogłaszania i publikowania za zgodą monarchy wszystkich praw, konstytucji sejmowych, uniwersałów, dekretów, przywilejów, akt publicznych i poleceń Rady Nieustającej. $Z$ rozważań Skrzetuskiego nie można zatem jednoznacznie wywnioskować, jaki był faktyczny i formalny wpływ króla na treść konstytucji sejmowych. Skrzetuski nie posługiwał się już bowiem w całości, poglądem swojego wielkiego poprzednika Lengnicha, który pisał: „Uchwały - tytuł królewski na czele mają i pod jego imieniem wychodzą. To samo już dostatecznie dowodzi, iż bez upoważnienia króla, dopóki żyje i panuje nie może być żadna wydana uchwała, a tem mniej taka, która by przeciw niemu coś orzekała” 20 .

18 Uznano, że przyjęte ustawy na konwokacji, pomimo braku króla, obowiązują i nie ma potrzeby sankcjonowania ich przez nowo wybranego monarchę, co ujęto m.in. tak: „tej są ważności i mocy, co i inne ustawy w czasie sejmów wszystkich, in plenis ordinibus przez stany zgromadzone zdziałane”, VL, t. VII, s. 138; por. R. Łaszewski, Sejm, s. 27-29. Warto dodać, że sprawę w zasadzie załatwiło wydanie w 27 czerwca 1789 roku konstytucji Ubezpieczenie czasu sejmowego, na mocy której król został zwolniony z obowiązku brania udziału w sesjach, a konstytucje przyjęte pod jego nieobecność miały pełną moc obowiązującą, VL, t. IX, Kraków 1889, s. 104.

19 Por. S. Konarski, O skutecznym rad sposobie, t. IV, Warszawa 1923, s. $193,238$.

20 G. Lengnich, Prawo pospolite, s. 165. Nieco inaczej rzecz ujmował ksiądz Kitowicz, który m.in. pisał: „Ani król, ani senat nie mieli vocem activam, dlatego w izbie senatorskiej żadnych ustaw nie pisano; całe pra- 
Dla charakterystyki wzajemnych relacji stanów sejmujących warto w tym miejscu wskazać, że Skrzetuski nie tylko nazywał króla głową narodu oraz pierwszym $z$ trzech stanów składających się na całość Rzeczypospolitej, ale również podkreślał, iż część uprawnień polski monarcha wykonywał sam, a część wspólnie $z$ dwoma pozostałymi stanami. Pijar pozwolił sobie też na ciekawy komentarz oceniający istniejący w Rzeczypospolitej podział władzy ustawodawczej pomiędzy królem, senatem oraz izbą poselską i zaznaczał, że do takiego kształtu relacji pomiędzy stanami sejmującymi doszło w istocie za sprawą dobrowolnej rezygnacji władcy z części przysługujących mu wcześniej uprawnień, których monarcha zrzekł się na rzecz narodu szlacheckiego ${ }^{21}$.

Prezentując inne relacje pomiędzy stanami sejmującymi, pijar przy okazji opisu przebiegu obrad jeszcze przed rozejściem się obu izb w celu prowadzenia odrębnych obrad wskazywał, że zarówno spis aplikujących do komisji skarbowych, jak i czytane przed połączonymi izbami propozycje od tronu rozdawane winny były być $\mathrm{w}$ formie pisemnej, co w pewnym sensie koresponduje także $z$ problemem zgodności programu królewskiego przedstawianego $\mathrm{w}$ początkach sejmu $\mathrm{z}$ treścią legacji rozsyłanej na sejmiki przedsejmowe. Właśnie kontrowersje, jakie na tym tle powstawały, doprowadziły w schyłkowym okresie rządów saskich do postulatu przekazywania posłom i senatorom uwierzytelnionego spisu królewskich propozycji, co miało $\mathrm{z}$ jednej strony uniemożliwić stronnictwu

wodawstwo w izbie poselskiej swój plan miało", J. Kitowicz, Opis obyczajów za panowania Augusta III, wyd. R. Pollak. Wrocław 1951, s. 603; por. R. Łaszewski, Sejm, s. 151-152.

${ }^{21}$ Pijar rozważał generalnie uprawnienia monarsze, o których pisał m.in. „Król Polski ma niektóre prawa sobie właściwe, insze $z$ dwoma drugiemi Stanami wspolne; do której wspolności Senat i Stan Rycerski przyszedł, już to dobrowolnym Krolów ustąpieniem praw swoich; już Paktami Krolom po Zygmuncie Auguście obieranym podawanemi, które do rozszerzenia wolności i swobod Narodowych dziwnie były przydatne”, W. Skrzetuski, Prawo polityczne, t. I, s. 103; por. Konarski, O skutecznym, t. III, s. 165 i n.; zob. też A. Grześkowiak-Krwawicz, Czy król potrzebny jest republice. Polscy pisarze polityczni wieku XVIII o miejscu i roli monarchy w Rzeczypospolitej. Zarys problematyki, [w:] Dwór a kraj. Między centrum a peryferiami wtadzy, red. R. Skowron, Kraków 2003, s. 476. 
królewskiemu modyfikowanie programu obrad, a z drugiej służyć dyscyplinowaniu wszystkich sejmujących w zakresie przedmiotu debaty parlamentarnej. Można przypuszczać, że pijar, mając na względzie wcześniejsze kontrowersje i zmiany regulaminowe, jakie zaszły w tym zakresie na skutek m.in. postulatów Familii, podkreślał okoliczność rozdawania sejmującym propozycji od tronu w formie pisemnej ${ }^{22}$.

Z kolei przy okazji opisywania przebiegu prac legislacyjnych sejmu Skrzetuski akcentował, że „proiekta wszelakie oddawane być powinny do laski; a Marszałek żadnego nie może nie przyjąć, nawet choćby w którym co oboiętnego albo dawnieyszym prawom przeciwnego, z Deputatami do konstytucji upatrzył, a podaiący go ostrzeżony o tym nie chciał poprawić, powinien dać do czytania nic w nim nie odmieniając”23. Analizowany obszernie przez R. Łaszewskiego problem dyskusji i głosowania nad poszczególnymi projektami Skrzetuski opisywał skrótowo, wskazując, że każdy projekt po przeczytaniu przez sekretarza sejmowego był rozdawany posłom i senatorom, a czas analiz był limitowany dwoma dniami do namysłu, a następnie „obydwie izby w iednymże czasie o nim decydują, wotuiąc per turnum, ieźliby iednomyślna zgoda nie zaszła; a turnus na każdego seymujacego żądanie bywa do trzech razy czyniony, $z$ trzecim wotowaniem sekretnym. Senatorska izba z poselską donoszą sobie przez delegatów o większości głosów na każdy proiekt, a dopiero ta złączona większość tworzy decyzją" ${ }^{24}$. Dla wzajemnych relacji stanów sejmujących oznaczało to w istocie m.in. formalne nadanie takiej samej rangi i znaczenia obu izbom. Skrzetuski podkreślał, iż ogłaszanie zarówno jednomyślnej zgody, jak i większości

22 W. Skrzetuski, Prawo polityczne, t. I, s. 284; szerzej zob. J. Michalski, Plan Czartoryskich, s. 35.

23 W. Skrzetuski, Prawo polityczne, t. I, s. 287. Marszałek miał jedynie poinformować izbę o tym, co jego zdaniem w danym projekcie jest błędne czy szkodliwe. Por. S. Konarski, O skutecznym, t. IV, s. 282; Zbiór mów $w$ czasie seymu sześcioniedzielengo roku 1784 mianych $w$ Grodnie, Wilno 1784, s. 405; J. Michalski, Plan Czartoryskich, s. 35; R. Łaszewski, Sejm, s. 135-136, 138.

24 W. Skrzetuski, Prawo polityczne, t. I, s. 288; por. R. Łaszewski, Sejm, s. $138-140,143-146$. 
głosów za danym projektem było stwierdzane równolegle w obydwu izbach, a w przypadkach równości głosów rozstrzygające znaczenie miał głos króla. Zaakceptowane w powyższy sposób projekty podpisywał marszałek $z$ deputatami do konstytucji.

Na marginesie rozważań nad głosowaniem w sejmie warto wskazać, że Skrzetuski w swoim podręczniku o prawie politycznym poza przedstawieniem zasad głosowania zaprezentował historyczny i współczesny rys liberum veto, w tym szczególnie kwestię jego zgubnego wpływu na losy państwa szlacheckiego, o czym pisał m.in. tak: „Skoro prawo głosu wolnego używane być poczęło na zrywanie Seymów, a zostawiona bez rady Rzeczypospolita widocznie szwankowała, uskarżali się na ten zbytek wolności dobrzy i oświeceni Obywatele" 25 . Skrzetuski przypominał przy tej okazji niektóre opinie i ostrzeżenia oraz niezrealizowane projekty reform i ubolewał, że „ani, te, ani inne podawane środki nie były dość skuteczne, a jednego, który mógł zapewnić seymów dochodzenie, doyźrzeć czyli raczej wskazać nie śmiano”, oraz akcentował, iż „o tym jedynie skutecznym Rad sposobie ośmielił się pisać Stanisław Konarski. A panowaniu Nayiaśniejszego Stanisława Augusta zostawiona była ta chwała, że po ulepszonych wszystkich rządu Kraiowego częściach, po ustanowieniu większości głosów w obieraniach wszelkich i w materiach Ekonomicznych; wolnego nie pozwalania prawo tylekroć tak szkodliwie użyte, określone iest do samych materyi Status, a tych wyraźnie wyszczególnionych, przez co przynaymniey po wielkiey części zapobieżono wzmagaiącemu się po każdym Seymie zerwanym, nierządowi”26. Skrzetuski nie tylko krytykował liberum veto, ale także, analizując relacje pomiędzy stanami sejmującymi, podkreślał zalety systemu głosowania przyjętego w 1768 roku, wskazując, że głosowanie w obu izbach jednocześnie pozwa-

25 W. Skrzetuski, Prawo polityczne, t. I, s. 288, 299; por. R. Łaszewski, Sejm, s. 146.

26 W. Skrzetuski, Prawo polityczne, t. I, s. 299-300; o propozycjach Konarskiego dotyczących głosowania zob.: S. Konarski, O skutecznym, t. IV, s. 207-209, 212, 223-226, 240-245; o projektach i próbach reform szerzej zob. H. Olszewski, Sejm, s. 326-342; S. Grodziski, Projekt reform prawno-ustrojowych z roku 1673, Czasopismo Prawno-Historyczne 1956, t. VIII, s. 168 i n.; R. Łaszewski, Sejm, s. 145-146. 
lało na unikanie powielania dyskusji w izbie wyższej nad projektem uchwalonym w izbie poselskiej. Analiza rozważań Skrzetuskiego w całej rozciągłości potwierdza ustalenia Profesora R. Łaszewskiego co do tego, że okrojona reforma z 1768 roku de facto oznaczała nie tylko ograniczenie liberum veto, ale i eliminowała praktykę podważania ważności wcześniej podjętych przez sejm uchwał. Prawa kardynalne przesądzały o tym, że pomimo sprzeciwu w sprawach dotyczących materii status dyskusja i prace nad tzw. kwestiami ekonomicznymi mogły biec dalej, a podejmowane decyzję stawały się obowiązującym prawem ${ }^{27}$.

Dla przedstawienia wzajemnych relacji stanów sejmujących w procesie tworzenia praw, jakie zaprezentował Skrzetuski w swoim podręczniku o prawie politycznym, warto zwrócić uwagę na końcowe rozważania pijara w tym zakresie. Wskazywał on bowiem, że w przypadku bezspornego zakończenia uzgadniania wszystkich projektów marszałek $z$ posłami wracał do senatu, gdzie następnie czytane były stanom zgromadzonym ułożone według projektów podpisanych konstytucje, które po przeczytaniu i porównaniu z oryginalnymi projektami marszałek i deputaci $z$ senatu i izby poselskiej podpisywali w obecności stanów. Skrzetuski akcentował przy tym, że od momentu ostatniego złączenia się izb nie można było przyjmować żadnych nowych projektów ${ }^{28}$. Pijar przy tej okazji poruszał problem przedłużenia obrad oraz limity i wskazywał krótko, że obrady sejmu „,ani przewlec nad niedziel sześć, ani limitować bez iednomyślnego zezwolenia stanów nie można" 29 .

Skrzetuski stosunkowo skromnie zaprezentował kwestię wzajemnych relacji między senatem a izbą poselską, choć jak wykazuje analiza R. Łaszewskiego, zagadnienie było poruszane przez publicystykę oraz pisarzy politycznych jeszcze u progu doby stanisła-

27 VL, t. VII, s. 291; por. R. Łaszewski, Sejm, s. 146-147.

28 W. Skrzetuski, Prawo polityczne, t. I, s. 289; VL, t. VII, s. 291; szerzej zob. R. Łaszewski, Sejm, s. 150-151.

${ }^{29}$ W. Skrzetuski, Prawo polityczne, t. I, s. 289. Skrzetuski przywoływał przy tej okazji konstytucję z 1768 roku, która nakazywała łączenie się izb pierwszego dnia ostatniego tygodnia i przypominał, że w 1786 roku za pozwoleniem króla i jednomyślną zgoda stanów posłowie pozostali w swojej izbie o jeden dzień dłużej, ibidem; VL, t. VII, s. 282; VL, t. VIII, s. 9, 10. 
wowskiej. Warto zatem za Jubilatem wskazać, że Stanisław Konarski proponował, aby rolą senatu było wnoszenie poprawek do projektów izby poselskiej, a w przypadku braku akceptacji posłów dla propozycji braci starszych sprawa miała iść $\mathrm{w}$ reces do czasu obrad następnego sejmu. Inaczej wzajemne relację senatu i izby poselskiej prezentowane były w projekcie Familii z 1763 roku, która chciała, aby obie izby miały równorzędną pozycję, a która wyrażała się m.in. w konieczności wzajemnego akceptowania uchwał podjętych przez posłów i senatorów. Czartoryscy proponowali także nadanie senatowi inicjatywy ustawodawczej ${ }^{30}$. W swoich analizach R. Łaszewski podkreślał także, iż z propozycją istotnego ograniczenia roli senatu w Rzeczypospolitej szlacheckiej wystąpił także J.J. Rousseau, który kwestionował m.in. konieczność samodzielnego udziału senatu w procesie tworzenia prawa. Ten wybitny myśliciel proponował, aby senatorowie jako przedstawiciele narodu współuczestniczyli w procesie ustawodawczym jedynie przez fakt współpracy z posłami szlacheckim. Jeszcze dalej w propozycjach dotyczących wzajemnych relacji pomiędzy izbą poselską a senatem posunął się M. Wielhorski, który odmawiając tej ostatniej izbie przymiotu stanu sejmującego, chciał dla senatorów jedynie prawa inicjatywy ustawodawczej oraz możliwość zasiadania na sesjach prowincjonalnych ${ }^{31}$. Warto przy tej okazji zauważyć, że Skrzetuski, odnosząc się w swoim Prawie politycznym do praktyki zwoływania sesji prowincjonalnych, na które zezwalał król na wniosek marszałka izby poselskiej, podawał, iż celem odrębnych obrad trzech prowincji odbywających się pod przewodnictwem pierwszych senatorów było doprowadzenie do zgody wszystkich posłów w przypadku występowania poważnych rozbieżności, oraz podkreślał, że nadal służą dla wybrania sędziów sądu sejmowego i załatwienia ważnych spraw poszczególnych prowincji ${ }^{32}$.

Generalnie należy stwierdzić, że Skrzetuski zagadnieniu zmian w funkcjonowaniu i pozycji senatu w Rzeczypospolitej szlacheckiej

30 W. Konopczyński, Polscy pisarze polityczni $w$ XVIII wieku, Warszawa 1966, s. 217; R. Łaszewski, Sejm, s. 67; J. Michalski, Plan Czartoryskich, s. 35-38.

31 R. Łaszewski, Sejm, s. 66-68.

32 W. Skrzetuski, Prawo polityczne, t. I, s. 295-296. 
poświęcił niewiele miejsca. Interesujące nas kwestie wzajemnych relacji pomiędzy senatem a pozostałymi stanami sejmującymi pijar opisywał głównie przy okazji zmian ustrojowych, w tym przede wszystkim w kontekście reformy regulaminu obrad sejmu i roli senatu po roku 1768. W porównaniu do swoich wielkich poprzedników, w tym szczególnie Konarskiego i Lengnicha, jego postulaty i oceny nie było ani zbyt dogłębne, ani nadto stanowcze.

Należy jednak odnotować, że pomimo tego w dziele Skrzetuskiego zawarto kilka interesujących propozycji i komentarzy, jak np. dotyczących liberum veto, choć akurat problem ewentualnego posiadania przez senatorów prawa sprzeciwu wobec uchwał poselskich dla Skrzetuskiego niemal nie istnieje, a rozważania polskiego pijara są dalekie od pełnego zaprezentowania roli i znaczenia senatu w sejmie dawnej Rzeczypospolitej. Jak wykazały badania Profesora R. Łaszewskiego, problem wzajemnych stosunków senatu i izby poselskiej, w tym pozycji senatu w sejmie, był złożony i żywo dyskutowany w XVIII-wiecznej publicystyce politycznej. Skrzetuski wydaje się wskazywać na to, że senat, pomimo dominującej roli izby poselskiej, w której w zasadzie rozstrzygano o treści przyjmowanych konstytucji, był organem współdecydującym, chociażby przez możliwość wyrażania swoich opinii w końcowej fazie obrad sejmu. Skrzetuski nie przeprowadził jednak dogłębniejszej analizy ustawy o porządku obrad z 1768 roku. Rozważania pijara nie obejmują już np. tego, czy senatorowie mieli prawo weta. $Z$ ustawy tej wynika bowiem, że wspólnie posiedzenie pod koniec obrad izby poselskiej i senatu służyło sprawdzeniu zgodności projektów uchwalonych w obu izbach. Skrzetuski nie analizuje także innych problemów związanych $z$ wzajemnymi relacjami obu izb, a na istnienie które zwracał uwagę R. Łaszewski, w tym na to, co działo się w senacie Z projektem, który upadł w izbie poselskiej ${ }^{33}$.

Końcowo warto podkreślić, że pijar, rozważając zagadnienie wzajemnych relacji pomiędzy stanami sejmującymi miejscami, dokonywał ciekawych historycznych dygresji, które pokazywały pewne słabości rozwiązań funkcjonujących w praktyce parlamentarnej I Rzeczypospolitej. Skrzetuski, omawiając stosunkowo nową proce-

33 R. Łaszewski, Sejm, s. 66-67. 
durę obrad sejmowych, nie zawsze w sposób wyraźny akcentował rozwiązania mające na celu uproszczenie i przyśpieszenie biegu posiedzeń sejmowych. Przy okazji opisywania praktyki przedstawiania propozycji od tronu pijar podkreślał, że pojawiające się często kontrowersje na tym tle doprowadziły do realizacji postulatu przekazywania posłom i senatorom uwierzytelnionego spisu królewskich propozycji, i wskazywał, że miało to z jednej strony uniemożliwić stronnictwu królewskiemu modyfikowanie programu obrad, a z drugiej służyć dyscyplinowaniu wszystkich sejmujących w zakresie przedmiotu debaty parlamentarnej oraz porządkować nie zawsze jasne relacje pomiędzy stanami sejmującymi.

Trudno jednoznacznie stwierdzić, czy Skrzetuski był zwolennikiem ograniczenia roli senatu, w tym także w sferze wzajemnych relacji $z$ innymi stanami sejmującymi. Dawał raczej wyraz dość powszechnie przyjmowanej ówcześnie tendencji, sprowadzającej senat głównie do instytucji pełniącej funkcję rady królewskiej. Dominujące w państwie szlacheckim tendencje republikańskie, w których kategoriach nie mieścił się senat powoływany przez monarchę, a nie naród szlachecki, niejako ze swej istoty rodziły postulaty likwidacji senatu lub co najmniej ograniczenie roli tej izby, a w planie minimum odebranie panującemu prerogatywy nominacji „braci starszych”. U Skrzetuskiego uwidacznia się jednak także tradycyjna pozycja i rola senatu, który według pijara stanowił jeden $z$ trzech $w$ istocie równoważących się stanów sejmujących.

Sumując rozważania na temat wzajemnych relacji stanów sejmujących, warto także zauważyć, że Wincenty Skrzetuski podkreślał, iż król nie może korzystać $z$ części swoich uprawnień bez zgody pozostałych stanów sejmujących, a w innych kwestiach dotyczących bieżącej polityki Rady Nieustającej. Pijar wielokrotnie akcentował konieczność współdziałania trzech stanów sejmujących, podkreślając przy tej okazji spójność władzy królewskiej w państwie szlacheckim $z$ narodem, co ujmował w tych słowach: „gdyżby to było rozrywać tę jedność, która się utrzymuje Rządu i Narodu Polskiego powszechna całość"34. Powyższe twierdzenie wydaje się dowodzić, że Skrzetuski był zwolennikiem poglądów uznających nieodzowność

34 W. Skrzetuski, Prawo polityczne, t. I, s. 107-108. 
istnienia króla w państwie szlacheckim oraz jego znaczenie w utrzymaniu równowagi w relacjach pomiędzy pozostałymi stanami sejmującymi, a także innymi organami władzy w państwie szlacheckim, nie mówiąc już o roli monarchy w utrzymaniu równowagi pomiędzy rządzącymi a rządzonymi oraz zagwarantowanie porządku w państwie szlacheckim ${ }^{35}$. Warto podkreślić, że Skrzetuski, opisując pozycję ustrojową monarchy Rzeczypospolitej, nie kwestionował tego, iż król jest pełnoprawnym stanem sejmującym, choć już w latach siedemdziesiątych XVIII stulecia pojawiły się głosy podważające prawotwórczą rolę władcy. To tradycyjne spojrzenie na pozycję króla w strukturze władz państwa szlacheckiego wydaje się przede wszystkim konsekwencją przyjętego przez pijara tradycyjnego modelu ustroju mieszanego $\mathrm{z}$ trójpodziałem na element monarchistyczny, arystokratyczny w postaci senatu i demokratyczny znajdujący uosobienie w izbie poselskiej ${ }^{36}$. Godzi się w tym miejscu zauważyć, że w Mowach o główniejszych materiach politycznych Skrzetuski znajdował się już pod pewnym wpływem filozofii J.J. Rousseau i K. Monteskiusza, w tym koncepcji podziału władz, umowy społecznej, suwerenności narodu ${ }^{37}$. $Z$ analizy poglądów polskiego pijara trudno jednak wysnuć wniosek, że negował on królewską prerogatywę polegająca na czynnym udziale w tworzeniu prawa. Nie można także sądzić, że Skrzetuski traktował króla wyłącznie już jako najwyższego urzędnika w państwie, choć w wielu miejscach swojego podręcznika pijar bardzo skwapliwie wskazywał na kompetencje króla w zakresie egzekutywy, podkreślając przy tym ograniczenia, jakie narzucono na władcę powołując Radę Nieustającą. Nie ulega natomiast wątpliwości, że Skrzetuski wielokrotnie akcentował podległość króla prawom Rzeczypospolitej oraz teorię równowagi przy stanowieniu prawa ${ }^{38}$. Należy zaznaczyć, że Skrze-

35 Por. A. Popławski, Zbiór niektórych materii politycznych, Warszawa 1774, s. 171-173; A. Grześkowiak-Krwawicz, Czy król jest, s. 471-472.

36 W. Skrzetuski, Prawo polityczne, t. I, s. 103, t. II, s. 272-273; S. Konarski, O skutecznym, t. I, s. 173. Szerzej zob. A. Grześkowiak-Krwawicz, Czy król, s. 477-478.

37 W. Skrzetuski, Mowy, s. 33 i n., 347 i n.

38 W. Skrzetuski, Prawo polityczne, t. I, s. 103, 105, 107; VL, t. VIII, s. 84-89. Zob. też na poglądy Skrzetuskiego wyrażone w mowie pt. O grun- 
tuski, podobnie jak wielu mu współczesnych, traktował króla, senat i izbę poselską jako niezbędne elementy władzy ustawodawczej w Rzeczypospolitej szlacheckiej, a których szczególnie ważnym zadaniem było spajanie i zachowanie równowagi pomiędzy szlachtą a magnaterią na gruncie szlacheckiego parlamentu.

\section{SUMMARY}

\section{Wincenty Skrzetuski about mutual relations between parliament class in gentry Republic of Poland (selected problems)}

Wincenty Skrzetuski's political views place him among the followers of the designers of the reform of the 18th century Republic of Poland. In his work on The Political Right of the Polish Nation, Skrzetuski described the principles according to which the Polish Parliament (Sejm) of those times functioned. Polish piarist made interesting historical digressions which showed some of the weak points of the solutions functioning in the parliamentary practice of the First Republic of Poland. Skrzetuski, discussing a procedure of parliamentary sessions, ammended in the period of Stanisław August Poniatowski, did not always clearly emphasise the solutions aiming at simplification and acceleration of the course of the parliamentary sessions. It needs to be emphasized that describing the problem of parliamentary clearances, he referred to disastrous parliamentary practices and was in line with some drafters of the reforms in the gentry Republic of Poland which demanded radical changes in the clearance procedure or even in its total abolishment.

Skrzetuski pointed to the fact that the senat is one of the three governing organs, the most important tasks of which is to serve and advice the king, as well as support him in performing some of public duties, including justice administration, being in charge of state unity as well as laws and citizenship freedom and mediating between a monarch and free gentry nation.

townej panujących chwale. W. Skrzetuski, Mowy, s. 187 i n. Por. A. Grześkowiak-Krwawicz, Czy król, s. 478-480. 
Skrzetuski was among those who were first to advocate the necessity of building a strong modern state. In his work on Speeches on major political matters he often warned that delaying reforms, such as introduction of the succession to the throne or maintaining the liberum veto principle, would lead to a decline and ultimate fall of the Republic.

Key-words: Wincenty Skrzetuski, Reforms in the gentry Republic of Poland (of the 18th century), Polish nobel freedom, functioning of the Parliament (Sejm) of the gentry Republic of Poland, polish piar 